\title{
Educação formativa de uma líder política cearense: Maria Luiza Fontenele (1950-1965)
}

\author{
The formative education of a political leader from Ceará: \\ Maria Luiza Fontenele (1950-1965)
}

Educación formativa de una líder política de Ceará: Maria Luiza Fontenele (1950-1965)

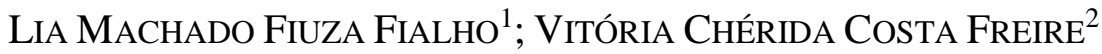

\section{Resumo}

O trabalho objetiva compreender o processo formativo na educação familiar, primária, secundária e universitária, bem como a inserção política (1950-1965) de Maria Luiza Fontenele, professora, educadora, política - a primeira mulher prefeita de uma capital brasileira - a cidade de Fortaleza-Ceará. Visando a esse alcance, utiliza-se a metodologia da História Oral no gênero biográfico (MEIHY; HOLANDA, 2007) para a coleta das entrevistas livres e a análise das narrativas. Constata-se que o curso formativo de Maria Luiza Fontenele começa com a alfabetização, em casa, com professora leiga, prosseguindo com a educação primária e secundária, respectivamente, no Colégio Sagrado Coração de Jesus e Colégio Nossa Senhora de Lurdes, com ideário mariano. A educação secundária, no Liceu do Ceará, ocorreu em concomitância com a formação política iniciada no Grêmio Estudantil e na Juventude Estudantil Católica. A educação superior na Universidade Federal do Ceará, no curso de Serviço Social, favoreceu-lhe o engajamento no Movimento Estudantil e a atuação sociopolítica, em especial na comunidade do Pirambu.

Palavras-chave: Formação escolar. Formação política. Educação de Mulheres.

${ }^{1}$ Doutora em Educação pela Universidade Federal do Ceará, com estágio de pós-doutorado realizado na Universidade Federal da Paraíba. Professora do Centro de Educação e do Programa de Pós-Graduação em Educação da Universidade Estadual do Ceará. Líder do Grupo de Pesquisa "Práticas Educativas, Memórias e Oralidades". E-mail: lia_fialho@yahoo.com.br

${ }^{2}$ Doutoranda em Educação no Programa de Pós-Graduação em Educação da Universidade Estadual do Ceará. E-mail: vitoria.cherida@aluno.uece.br 


\begin{abstract}
This paper aims to understand Maria Luiza Fontenele's educational process firstly within her family, later in primary and secondary institutions, and lastly at university, along with her political insertion (1950-1965). Maria Luiza Fontenele is a teacher, an educator and a politician: the first female mayor of a state capital in Brazil, specifically Fortaleza, in Ceará. Thus, the methodology is based on the biographical genre of Oral History (MEIHY; HOLANDA, 2007) for the collection of open interviews and the analysis of narratives. We conclude that Maria Luiza Fontenele's education began with literacy at home with a lay teacher, and continued with primary and secondary education, respectively, at "Colégio Sagrado Coração de Jesus" and "Colégio Nossa Senhora de Lurdes", with Marian ideals. Secondary education, at "Liceu do Ceará", took place in concomitance with her political education initiated at the Student Guildand the Young Catholic Students. Her higher education studies in Social Work, at the "Universidade Federal do Ceará", enabled her engagement in the Student Movement and her social and political activities, especially in Pirambu.
\end{abstract}

Keywords: School education. Political education. Women education.

\title{
Resumen
}

El trabajo tiene como objetivo comprender el proceso formativo en la educación familiar, primaria, secundaria y universitaria, así como la inserción política (1950-1965) de Maria Luiza Fontenele, profesora, educadora y política - la primera alcaldesa de una capital brasileña, Fortaleza, en la provincia de Ceará. En este sentido, se utiliza la metodología de la Historia Oral en el género biográfico (MEIHY, HOLANDA, 2007) para la recolección de las entrevistas libres y el análisis de las narrativas. Se constata que el curso formativo de Maria Luiza Fontenele comenzó con la alfabetización, en su casa, con una profesora lega, siguiendo con la educación primaria y secundaria, respectivamente, en los colegios "Sagrado Coração de Jesus" y "Nossa Senhora de Lurdes", con ideario mariano. La educación secundaria, en "Liceu do Ceará", tuvo lugar junto con su formación política, iniciada en el Gremio Estudiantil y en la Juventud Estudiantil Católica. La educación superior la tuvo en la "Universidade Federal do Ceará", en el curso de Trabajo Social, que le favoreció el compromiso con el Movimiento Estudiantil y con la actuación sociopolítica, principalmente en Pirambu.

Palabras clave: Formación escolar. Formación política. Educación de mujeres. 


\section{Introdução}

Maria Luiza Fontenele foi a primeira prefeita mulher eleita numa capital brasileira, pelo Partido dos Trabalhadores (PT), após o período da ditadura civil-militar, na cidade de Fortaleza-Ceará (1985). Juntamente com companheiros políticos cearenses, esteve à frente do movimento reivindicatório pelas "Diretas Já", em 1983, que defendia eleições diretas para a presidência do Brasil. A forte militância de Maria Luiza, inclusive com passagem pelo Partido do Movimento Democrático Brasileiro (PMDB) e a proximidade com o Partido Revolucionário Comunista (PRC), ensejou visibilidade social associada à sua presença marcante no Congresso Nacional, em comícios e em movimentos populares que lutavam por mudanças no contexto político brasileiro, o que favoreceu sua candidatura no município de Fortaleza, após a aprovação da lei das eleições diretas para as prefeituras de capitais brasileiras.

Recém-integrada ao Partido dos Trabalhadores (PT), a candidatura e eleição de Maria Luiza representou a vitória do povo e de uma mulher que venceu os tradicionais coronéis e militares políticos cearenses com o intuito de estabelecer uma administração popular. Mas o seu mandato, considerado à época como mandato-tampão, durou três anos (1986-1988) e enfrentou muitas dificuldades devido a diversas formas de preconceitos que sofreu, no contexto de pós-ditadura militar, não só por ser mulher mas também por ser egressa de movimentos e partidos considerados de esquerda.

Ao romper com o governo do Estado do Ceará, responsável pelo repasse de verbas para as prefeituras, Maria Luiza travou um embate político, de tal modo insustentável que a fez decretar estado de emergência (VIEIRA BRUNO; FARIAS; ANDRADE, 2002).

Embora sua visibilidade e reconhecimento sejam maiores por sua atuação como prefeita na cidade de Fortaleza, Maria Luiza também exerceu o cargo de Deputada Estadual (1979) e Deputada Federal (1990). Além disso, foi professora do Curso de Ciências Sociais, da Universidade Federal do Ceará (UFC) por onze anos, tendo de conciliar sua atividade docente com sua atuação sindical e em grupos feministas e de anistia política.

Essa reconstituição de sua trajetória, induz ao seguinte questionamento: a educação de Maria Luiza Fontenele - familiar, primária, secundária e universitária - ensejou formação para que ela pudesse tornar-se uma líder política que galgou prestígio e visibilidade social nos tempos em que apenas homens ocupavam os espaços decisórios na política brasileira? A pesquisa, em congruência, objetiva compreender o curso formativo na educação familiar, primária, secundária e universitária, bem como a sua inserção política (1950-1965).

Apesar de sua visibilidade social, especialmente no Ceará, a busca por produção científica que pudesse explicar sua trajetória educativa constatou que nada havia sido produzido sobre a temática, já que uma pesquisa prévia foi realizada no Banco de Dissertações e Teses do Centro de Aperfeiçoamento de Pessoal de Ensino Superior - CAPES, na base de dados Scientific Eletronic Library Online - Scielo e no Portal de Periódicos do Centro de Aperfeiçoamento de Pessoal de Ensino Superior - CAPES, em maio de 2017, com o descritor "Maria Luiza Fontenele", e se verificou que apenas quatro produções possuíam Maria Luiza como mote (CALIXTO, 2002; COELHO, 2014; BRAGA NETO, 2011; BRILHANTE, 2011). Estes, no entanto, restringiram-se a retratar sua administração pública. 
Atualmente, em 2017, com 75 anos de idade, Maria Luiza está aposentada, mas continua exercendo atividades educativas e políticas, não através da organização formal em instituições, partidos ou sindicatos, e sim na militância do grupo Crítica Radical ${ }^{3}$, em que cumpre uma agenda de atividades, como palestras, seminários, mesas-redondas e demais eventos, sempre apresentando um posicionamento de crítica à estrutura do sistema capitalista e político atual.

Importa destacar que a história de um indivíduo é influenciada pela sociedade a qual pertence; mas, além disso, vale lembrar que os sujeitos e os grupos também interferem na constituição da história de sua sociedade, por isso o papel do indivíduo pode ser tão importante no processo de constituição social. A relevância de analisar o curso formativo na educação familiar, primária, secundária e universitária, além da inserção política (1950 a 1965) de Maria Luiza está no fato de que, ao historiarmos a sua trajetória educativa, podemos compreender o lugar social em que ela estava inserida, bem como os paradigmas socioculturais rompidos, no que concerne à formação educacional feminina para possibilitar a representatividade política no cenário local e nacional.

Toda pessoa, seja um ser anônimo, seja um ser de grande representatividade social, possui uma história de vida que constitui a História; e a trajetória de Maria Luiza Fontenele, produto de individualidades, foi compreendida na sua interface com o coletivo, considerando aspectos sociais, culturais, econômicos e políticos que contribuíram para a compreensão da História da Educação, em especial no que diz respeito à educação feminina na sociedade cearense do início da segunda metade do século XX. Assim, a ação de narrar uma vida envolve um trabalho micro-histórico de caracterizar e personalizar esse personagem no imbricamento com o todo, vasto e complexo, ampliando a compreensão macro-histórica ao ensejar uma análise mais minuciosa que considera subjetividades (LORIGA, 2011) e desvela minúcias irrefutáveis para a compreensão da historiografia.

\section{Recorte metodológico}

Os estudos sobre a mulher na sociedade só ganharam maior relevância a partir das mudanças ocorridas na historiografia com o movimento de Annales. A "Nova História" proporcionou a ampliação de fontes para a historiografia e a possibilidade de estudos, nas Ciências Sociais e Humanas, sobre o homem, suas relações, seu cotidiano e imaginário, dentre outros aspectos da sociedade, e seu comportamento (BURKE, 2008). As transformações historiográficas abriram espaço para o estudo do presente, incluindo os aspectos políticos, culturais, e sociais do homem; isso possibilitou a legitimidade das fontes orais (FERREIRA, 1998) e, consecutivamente, o amparo teórico-metodológico da pesquisa em História Oral no gênero biográfico, com ênfase na educação e na vida política de Maria Luiza Fontenele, contemplando-se também os paradigmas socioculturais rompidos para a sua

\footnotetext{
${ }^{3} \mathrm{O}$ grupo Crítica Radical é composto por integrantes que romperam com a política partidária no Ceará e propõem uma reestruturação da estrutura social a partir de lutas emancipatórias e apartidárias. Têm como principais integrantes: Maria Luiza Fontenele, Rosa Fonseca, Jorge Paiva e Célia Zanetti, o grupo que contribuiu, de forma significativa, para a reorganização dos movimentos sociais e sugere uma ruptura com o sistema capitalista vigente.
} 
atuação como educadora e como política. "A nova história é a história escrita como uma reação deliberada contra o "paradigma' tradicional, aquele termo útil, embora impreciso" (BURKE, 1992, p.10, grifo do autor).

O movimento e a revista dos Annales (fundado por Bloch e Febvre, em 1929) são o marco, real ou simbólico, dessa nova escrita da história supracitada, que se opõe à narrativa predominantemente factual, heróica e descritiva, valorizando novas abordagens metodológicas e ampliando o campo de pesquisas e temáticas, em especial para a História da Educação, na sua terceira geração. Com essa compreensão, não se pretende uma narrativa heróica de Maria Luiza; ao contrário, busca-se a vida real, com os percalços, os sucessos e os problemas de seu tempo.

Fundamentando-se nos estudos da História Cultural, no âmbito da "micro-história", esta pesquisa viabiliza o estudo das histórias vividas por Maria Luiza a partir de particularidades, subjetividades e minúcias sobre como uma mulher percebe e lida com o mundo social, através de aproximações, conflitos e contratos (LORIGA, 2011). Afinal, a utilização de memórias e narrativas de pessoas que vivenciaram acontecimentos importantes permite a percepção da realidade social como uma elaboração cultural (MACHADO, 2006).

Utilizamos a metodologia da História Oral Biográfica, que permitiu uma reflexão sobre a experiência obtida durante a trajetória educativa de Maria Luiza, e os aspectos formativos que impulsionaram sua militância política. A História Oral é uma metodologia de pesquisa que se refere à realização de entrevistas com indivíduos protagonistas ou testemunhas de acontecimentos e conjunturas no tempo, decorrido ou presente. Essa metodologia não corresponde apenas à entrevista ou fonte oral, mas a um conjunto de ações planejadas desde um projeto previamente elaborado (MEIHY; HOLANDA, 2007).

Por intermédio da História Oral, utilizaram-se as memórias de Maria Luiza para valorizar a história e sua identidade (SILVA, 2009). O conceito de memória, nesse caso, pode ser definido como a propriedade de conservar informações, na qual ativamos um conjunto de funções psíquicas que nos possibilita recordar e atualizar impressões antigas, e ainda o modo como estas foram processadas e/ou foram representadas como passadas (LE GOFF, 1990). Posto que o trabalho da História Oral é lidar com lembranças e esquecimentos, subjetividades, experiências de vida, significações, ressignificações, representações sociais, funções psíquicas, afetividade, percepções, entre outras emoções e vivências, este trabalho não teve como objetivo o alcance de uma verdade histórica; seu intuito foi o de ampliar a compreensão da memória individual e/ou coletiva (MAIA; BRAGA; FIALHO, 2015) para desvelar a vida de Maria Luiza.

Biografar por meio do percurso metodológico da História Oral é recontar a trajetória de vida de um ser único, considerando sua identidade a partir de suas atitudes e de suas palavras. Nesse percurso, o pesquisador tem como objeto de investigação a vida, vista por sua própria "lente", pela qual irá interpretar e reconstruir sua trajetória (ALBERTI, 2005). Além do pesquisador, a singularidade e a identidade do biografado também estão sujeitas às circunstâncias históricas. A Biografia como gênero da História Oral pôde proporcionar maior visibilidade a Maria Luiza, na história, revelando trajetórias, experiências, saberes e demais aspectos que promoveram reflexões sobre o 
papel feminino na sociedade e na atuação educacional, profissional, política e histórica. Compreender a história da mulher pressupõe compreender as transformações na sociedade, na cultura, na política, na educação, entre outros aspectos.

Como instrumento de coleta de dados foi utilizado o recurso da entrevista livre em História Oral (MEIHY; HOLANDA, 2007), de modo a valorizar o que Maria Luiza considera relevante acerca da sua educação familiar, escolar, universitária e de sua inserção política. Ao todo, foram realizadas três entrevistas, com duração de aproximadamente $1 \mathrm{~h} 30 \mathrm{~min}$ cada uma. Esses relatos orais - salvos por gravações eletrônicas, transcritos, transcriados e validados pela biografada (MEIHY; HOLANDA, 2007) - tornaram-se o registro basilar para analisar e compreender a formação educativa e a iniciação política de Maria Luiza na interface com o contexto sócio-histórico, possibilitando contribuir com a História da Educação. Os resultados, tanto no formato oral oriundo das gravações, quanto na forma documental após as transcrições, foram arquivados no acervo do Grupo de Práticas Educativas, Memórias e Oralidades da Universidade Estadual do Ceará (UECE).

A entrevista em História Oral exprimiu-se como uma expressão democrática e a utilização das narrativas orais (o direito de falar) foram inerentes à sistematização do conhecimento socializado por Maria Luiza, especialmente porque muitos aspectos primordiais para a compreensão da formação educativa da biografada, no imbricamento com o contexto histórico, social e cultural, por exemplo, não estão registrados na historiografia oficial, devendo ser, portanto, considerados (FIALHO; CARVALHO, 2017). Dessa forma, a memória de Maria Luiza, que é sujeito único desta pesquisa, constitui uma ferramenta importante para se compreender e registrar sua educação e formação política ao romper paradigmas e quebrar uma histórica hegemonia coronelista de alternância de poder político no Ceará. Analisar a biografia de Maria Luiza contribui, em suma, com a compreensão historiográfica da educação feminina, especialmente no início da segunda metade do século XX no Ceará.

\section{A Infância, o início da escolarização e o contexto familiar de Maria Luiza Fontenele}

Maria Luiza Fontenele nasceu no ano de 1942, no Povoado da Serra, em Quixadá, interior do Estado do Ceará, no período em que a seca dominava a região sertaneja. A seca de 1942 afetou especialmente o Ceará, o Rio Grande do Norte e a Paraíba. Em 1941, os relatórios enviados ao Ministério da Viação já informavam a irregularidade e as deficiências de chuvas no inverno, bem como o predomínio de verão prolongado. Essa irregularidade pluviométrica tornou-se mais ameaçadora em 1942, quando a seca foi oficialmente reconhecida. Apesar do contexto de fome e de dificuldade econômica ocasionada por uma das mais severas secasno nordeste brasileiro, que flagelou muitas famílias (MEDEIROS FILHO; SOUZA, 1983), a seca não interferiu na situação econômica da família de Maria Luiza, que, apesar de viver de forma humilde, estava em ascensão, pois parte da família cuidava da criação de vacas em Fortaleza e destinava a produção de queijo e leite para Quixadá, onde abasteciam o comércio da região e obtinham lucro suficiente para a subsistência. 
Maria Luiza Fontenele foi a sétima filha, nascida do casal Antonino Barreira Fontenele e Diva Acreana de Menezes, que formaram uma família com oito filhos. Durante toda a infância, Maria Luiza morou no interior de Quixadá-CE. Juntamente com a irmã mais nova, recordou os tempos de criança em que fazia muitas "danações":

E o que me lembra muito da infância eram essas coisas que a gente fazia de danação, assim, por exemplo: insultar um animal e sair correndo pra ele não pegar, e pulava a porteira [...] ou então ia pra árvore, para o galho mais alto para pular dentro do rio. [...] Os meninos faziam uns carrinhos de madeira e a gente queria ser mais veloz que os meninos [...] Então, aos nove anos, eu não lembro da escola, mas lembro perfeitamente das danações: os folguedos, assim de coisas de fogueira, ainda hoje eu ainda lembro as músicas ou então a gente fazia muitas dramatizações (MARIA LUIZA, 2016).

Conclui-se que os folguedos, as festas populares realizadas anualmente, em muitas regiões brasileiras, fizeram parte da infância de Maria Luiza, que, desde cedo, esteve imersa em um contexto de ludicidade, com brincadeiras livres, cirandas, dramatizações, criação de músicas para apresentações na família, muitas vezes ao redor da fogueira. Além disso, os mitos e lendas também fizeram parte do imaginário infantil de Maria Luiza, como ela mesma relembra:

[...] à época eu tinha medo de alma, e tinha medo do cão, eu tinha medo de coisas que eu não sabia explicar, que o povo falava no sertão, né?! O Sacipererê, a Caipora, então, essas coisas assim que povoavam, digamos, os meus sonhos ou insônias e eu expressava para mãe esse mal estar dizendo que sentia dor de barriga, e eu acho que era mais medo do que propriamente a dor real (MARIA LUIZA, 2016).

A formação do ideário cristão, com a dicotomia céu-inferno e as concepções e convicções da Igreja Católica, esteve presente na sociedade brasileira, mais fortemente, desde a chegada dos portugueses. Sob a ótica do catolicismo, como as obras de Deus são perfeitas, as imperfeições são atribuídas ao poder diabólico, responsável e reprodutor de todos os males. Assim, a figura do demônio deveria ser temida pelo homem, por ser um inimigo que levava todos para o caminho da perdição. Essa dualidade entre o bem e o mal, imersa no imaginário de nossa sociedade pela Igreja Católica, prevaleceu durante muitos anos (AZZI, 2008). Os pais de Maria Luiza criavam seus filhos transmitindo esse ideário católico, fazendo-os temer, crer, fazer preces e rogar por bênçãos contra o demônio e suas malfeitorias. Tais valores eram repassados para Maria Luiza, tanto no seio familiar quanto na escola católica que frequentava. Acrescente-se ainda, a essa educação cristã, as lendas folclóricas, disseminadas de geração em geração, especialmente pela oralidade, no interior cearense, que perpassavam a memória herdada (POLLAK, 1992) e geravam sentimentos negativos naquele ser em formação.

As memórias da biografada sobre a família são reconstituídas com muito afeto: a união entre os irmãos; a imagem do pai como exemplo de homem especial, respeitador, culto e querido, e da mãe amorosa e dedicada ao bem estar dos filhos e do esposo. Não obstante sua inegável admiração pela mãe, ressalva não ser esse o exemplo de vida que 
gostaria de seguir, em uma referência ao ser dependente do marido e exclusivamente dona de casa. Apesar de uma formação familiar inicialmente voltada para a santidade, pois seu pai lhe conferia o desejo de ingresso na vida religiosa, como freira, Maria Luiza toma como exemplo a trajetória de seu pai e demonstra uma vontade contrária a este ideal, ansiando por atividades consideradas masculinas:

A minha mãe, eu dizia que [...] quando ela chegasse no céu e perguntassem: 'O que foi que fizeste na terra?!' A música é 'Só dançar, só dançar [...]'. E era uma das músicas que a gente cantava nas dramatizações. Então eu dizia que ela tinha feito só amar! Ela externava um bem dela a todas, a todos os filhos, foi o que me passou, foi isso. Uma mãe que chorava quando os filhos partiam, então foram duas coisas que marcaram minha vida, uma delas era de não amar para chorar, não ficar triste e a outra, acho, de não querer ser mãe. E ela dizia que quando eu era criança, em todas minhas brincadeiras, ela disse que nunca viu eu brincar de ser mãe das bonecas, eu era a comadre que ia visitar outra, a médica e a professora [...] (MARIA LUIZA, 2016).

De fato, segundo sua percepção, parece não haver absorvido muitas características de sua mãe; desde cedo, problematizou o ideal de formação católico mariano que recebeu, tanto da família quanto das instituições religiosas em que estudou. E sempre questionou o papel de mãe, rainha do lar, obediente e subserviente ao marido, que tinha como principal atribuição o cuidado com a casa e com os filhos, sendo esposa boa e prendada (VASCONCELOS; FIALHO; MACHADO, 2017).

O início da escolarização de Maria Luiza aconteceu na sua própria casa, em Quixadá-CE, onde, num quarto mais isolado do restante da casa, uma professora ministrava aulas de primeiras letras para as crianças da fazenda: "Então, eu sei que eu estudei um pouco em uma escola [...] dentro da nossa própria casa, num quarto mais afastado, mas não me lembro absolutamente de nada" (MARIA LUIZA, 2016).

Nesse contexto dos séculos XIX e XX, vale ressaltar que o interior do Ceará, assim como a província, de modo geral, foi uma região em que a educação formal passou por um processo lento de sistematização e consolidação, tendo em vista os seguintes fatores: a falta de recursos para a construção de prédios escolares próprios do governo, a compra de material escolar adequado, a má fiscalização do ensino, e o pequeno número de professores habilitados, devido à criação tardia da primeira Escola Normal (GIRÃO, 1962). Durante o período Imperial, estava claro que "[...] todo indivíduo tinha autoridade de ensinar a ler e escrever, manifestando as suas ideias, boas ou más, e de abrir colégios e escolas" (CASTELO, 1970, p. 47).

Como não havia curso de formação de professores nesse período histórico cearense, o magistério foi assumido, em sua maioria, por professoras leigas, devido à representação da figura da mulher estar associada com o cuidado, com a maternidade e o lugar do ensino como extensão do lar. Essas professoras, que necessitavam apenas comprovar boa moral e conduta perante a sociedade, foram as principais responsáveis pelo nível de ensino de primeiras letras e primário. De acordo com Therrien (1991), elas representavam a própria organização do sistema educacional público nas cidades interioranas cearenses, destinadas ao ensino rudimentar da leitura e das operações matemáticas às crianças, quando ainda não havia 
formação específica para o magistério, nem sistematização do ensino. Ministravam aulas em locais improvisados e muitas vezes sua prática não era espontânea; fazia-se em troca de auxílio financeiro das famílias que estavam em ascensão econômica no campo e precisavam instruir seus filhos, como foi o caso de Maria Luiza.

Maria Luiza recebeu instrução elementar em casa, ensino denominado de "Primeiras Letras", que tem referência na legislação educacional desde o período imperial no Brasil, quando Dom Pedro I, pela Lei de 15 de Outubro de 1827, determinou a criação de escolas e a liberdade do ensino de ler, escrever e contar (MENEZES, 1966). A instrução por meio de escolas de Primeiras Letras ocorreu durante longo período no cenário cearense, pois, mesmo antes da organização do ensino e do currículo dos níveis primário e secundário, estes demoraram a se efetivar. Por isso, o ensino das primeiras letras estendeu-se por muitos anos, paralelamente aos demais níveis de ensino, sendo ministrado em casa, principalmente no interior do Ceará, pelo fato de o acesso à escola ser mais difícil.

Importa esclarecer que as escolas de primeiras letras, no território cearense, que estiveram presentes até meados do período republicano, não se estabeleceram em prédios escolares (ou do governo); elas se instalavam nas residências dos próprios professores, e estes recebiam pequenos salários e uma contribuição do governo para o pagamento do aluguel. Também era comum o funcionamento dessas escolas em espaços improvisados, como igrejas, prédios comerciais ou salões. Além disso, “[...] têm-se indícios de que a rede de escolarização doméstica, ou seja, do ensino e da aprendizagem da leitura, da escrita e do cálculo, mas sobretudo daquela primeira, atendia a um número de pessoas bem superior ao da rede estatal" (VIDAL; FARIA FILHO, 2005, p. 45).

No caso de Maria Luiza, ela recebia, na sua própria residência, a professora, que, no período, era chamada de mestre de primeiras letras; ensinava a ela, aos irmãos e à filha da empregada de sua casa. A Lei de 15 de Outubro de 1827 (art. $6^{\circ}$ ) traz referência ao que se deveria ensinar aos alunos: ler, escrever, contar de acordo com as quatro operações básicas, Geometria prática, a Gramática da Língua Nacional, a Doutrina católica apostólica romana e seus princípios morais, bem como as regras de civilidade (MENEZES, 1966). Maria Luiza recebeu, na medida do possível, formação semelhante a este currículo, que era padronizado para esse nível de ensino na época. Aprendeu, em consonância, os elementos iniciais da leitura, da escrita e da aritmética por intermédio dessas aulas recebidas em casa.

A formação inicial, tanto dos conteúdos curriculares elementares - ministrados na "educação formal" em casa - quanto dos princípios que foram disseminados pela família (na educação informal) inspirava-se nos ideários da religião católica. Nesse sentido, a escolha de uma instituição confessional de ensino primário, na qual Maria Luiza, posteriormente, continuaria sua formação educacional, foi importante para sua família, na medida em que reforçava os valores e as condutas que ela já havia recebido na convivência com os pais, conforme veremos adiante.

\section{Ensino primário, secundário e a inserção em movimentos estudantis e católicos}

Maria Luiza foi matriculada por seus pais, juntamente com as duas irmãs mais novas, numa instituição confessional de renome na cidade de Quixadá-CE, o Colégio Sagrado Coração de Jesus. Iniciou os estudos no espaço formal de ensino, no terceiro ano do Ensino Primário, pois, além da idade compatível com a série, ela já havia sido instruída em casa e 
aprendido a ler, escrever, e realizar as quatro operações básicas matemáticas (adição, subtração, multiplicação e divisão). Mas sua experiência nesse colégio durou apenas um semestre, justamente pelo fato de a escola seguir com firmeza uma educação doutrinária católica apostólica romana e seus princípios morais prezarem pela formação religiosa e pelo matrimônio, como era de costume nas instituições que atendiam o público feminino mais abastado e congruente à formação inicial que Maria Luiza havia recebido no lar.

O colégio Sagrado Coração de Jesus estava sob a direção das religiosas alemãs da Congregação das Irmãs Missionárias da Imaculada Conceição da Mãe de Deus, que se estabeleceram no Brasil em 1910, mas também empreenderam obras educacionais e assistencialistas em outros países, como os Estados Unidos, Alemanha, Taiwan e Namíbia (África). A madre Imaculada de Jesus, Elisabeth Maria Gertrudes,que era de origem alemã, recebeu, em 1907, diploma de professora, na Escola Normal de Westfália, dedicando-se ao magistério a partir de então. Após receber uma carta de sua superiora, ela decide ir para o Brasil a fim de se dedicar ao projeto educacional de sua congregação no país. Além da formação humanística, a instituição pautava-se na formação do cristão fiel, justo, envolvido com as causas católicas que estivessem sempre a serviço da "construção do Reino de Deus" e sua expansão.

O colégio Sagrado Coração de Jesus foi fundado em 1938, pela Irmã Plácida e pelo Padre Luis Braga Rocha. Inicialmente, funcionou em anexo à Paróquia de Quixadá, até ser construído o prédio próprio, com a ajuda das irmãs alemãs. A priori, ofertou ensino primário às crianças e aos jovens, fundamentado na formação cristã. A partir de 1940, o colégio passou a oferecer outros cursos, como o de Admissão, Complementar e Normal Rural. Em seguida, ofertou o Curso Ginasial, em 1954. O curso Normal compõe a oferta da instituição a partir de 1958. A metodologia da instituição colocava em foco a palavra de Deus, através da Bíblia cristã, e o carisma da Congregação das Irmãs Missionárias da Imaculada Conceição, que valorizava o amor e o serviço, a piedade e a oração. Percebemos que a formação cultural humana, aliada ao comportamento cristão católico, era almejada pela instituição, ou seja, os conteúdos referentes à cultura humanística, às línguas e às artes eram ali evidenciados.

Maria Luiza recorda que começou a namorar muito cedo, durante suas férias escolares, com um jovem da comunidade, e que sua sexualidade foi aguçada precocemente devido à pureza e à naturalidade que observava nas relações entre os animais, que constantemente via no sertão. A sexualidade, no entanto, foi controlada fortemente pela escola, que lhe impunha repreensões e castigos com a alegação de zelar pela pureza e virgindade das moças, conforme sua narrativa exprime: “[...] logo o meu pai tomou conhecimento, através de uma besteira que eu fiz, que foi guardar os bilhetinhos que o rapaz mandava [...] no colégio. As freiras pegaram dentro do meu travesseiro [...]"(MARIA LUIZA, 2016). A sexualidade foi o ponto de maior controle e punição nas escolas católicas, tendo em vista que a virgindade era considerada como o maior "bem feminino", e a sua perda antes do casamento resultava na rejeição familiar e social. O despertar da sexualidade exigia controle e a sua manifestação estava sempre acompanhada da punição e/ou da culpa (FOUCAULT, 1998).

Maria Luiza narrou sobre outro ocorrido dentro da instituição, quando, após encontrar uma versão erótica de uma música em suas mãos, a freira demonstrou seu poder de controle e de repressão ordenando sua punição, qual seja, o isolamento na "cafua": "Mas 
quando a gente se danava demais ia pra um lugar chamado cafua. Era um quartinho fechado debaixo da escada; e eu fui uma vez pra essa cafua e odiei. Você tinha a sensação de prisão, mas foi só uma vez, mas odiei!" (MARIA LUIZA, 2016). O castigo da "cafua" consistia no isolamento, em local onde não se via o lado de fora, tampouco a luz do dia ou do luar. Para uma criança ou uma jovem, ser jogado naquele lugar, perdendo o controle da hora e sem saber quanto tempo iria permanecer ali, era, de fato, um castigo rigoroso.

Para além do castigo corpóreo, havia o castigo da alma; afinal, o ato de falar sobre sexo já constituía uma forma de controle, já que não era permitido pensar, falar ou fazer algo relacionado ao assunto (FOUCAULT, 1998). Ou seja, o controle tornava-se negação. E as escolas foram os locais de maior exercício de controle e moralização. A disciplina era “[...] a técnica específica de um poder que toma os indivíduos ao mesmo tempo como objeto e como instrumento de seu exercício" (FOUCAULT, 1998, p. 143). Com o disciplinamento dos corpos e das condutas, as freiras incutiam o modelo de Maria. Este modelo mariano de ser não dizia respeito apenas aos ritos e devoções, mas à própria vivência e prática cotidiana a fím de se alcançar uma "pureza" e a virgindade.

De acordo com o modelo instituído pela Igreja Católica, o bom cristão era aquele que tinha conhecimento das verdades da fé, seguia os preceitos morais e recebia frequentemente os sacramentos da confissão e da comunhão. Maria Luiza, na percepção das freiras, incorria em perigo ao se envolver precocemente com homem em namoricos e desobedecia a norma de ser recatada, assexuada, devota apenas aos estudos e a Deus. E, ainda que Maria Luiza considerasse que o ensino a ela oferecido fosse de qualidade - teve acesso às artes, às ciências e às línguas -, não aceitava os ideais de formação das irmãs que a escondiam do mundo, educando-a para ser boa esposa, prendada e mãe exemplar; de modo que sempre que possível se envolvia nas chamadas "atividades extras", realizadas fora da escola, no intuito de poder driblar os mecanismos de controle impostos no internato: "Eu era do coral do colégio, então, assim, quando o padre dizia: 'Quem quer fazer obra das vocações sacerdotais?' Eu já tava dentro do carro pra ir atrás de pedir coisa fora, né! Do colégio” (MARIA LUIZA, 2016).

A atuação das religiosas na educação aponta um fator importante para a análise histórica desse período: as freiras consideravam o lar como um lugar privilegiado da mulher, e o magistério como uma extensão deste, ou seja, era propícia à mulher a profissionalização docente. Tal ideal deveria ter sido basilar para incentivar Maria Luiza a desenvolver sua primeira experiência docente: “[...] eu devia ter 13, 14 anos, quando fui dar aula de adulto lá nessa escola ao lado do colégio, mas saía para dar aula (risos), e via outras pessoas" (MARIA LUIZA, 2016). A inspiração para que Maria Luiza ingressasse no magistério, contudo, não se deu exclusivamente pela intenção solidária ou formativa; ao contrário, a principal motivação era poder sair do internato e manter contato com a sociedade e com o mundo externo à congregação. A experiência de Maria Luiza como professora de adultos teve a mesma duração de sua vivência como interna na instituição, aproximadamente por um semestre, pois ela alega que a rigidez das irmãs e a forma como elas percebiam o mundo não estavam de acordo com suas vontades e aspirações:

Aí eu comecei a ter choques em relação ao que as freiras achavam pecado e eu não achava, quer dizer, não via como pecado. Uma dessas coisas era namorar, dançar. Eu não achava que tinha nada demais; aí eu não disse para minha mãe não, porque eu sabia que ela não decidia. Eu disse para o meu pai: 'Meu pai, eu não quero continuar no colégio de freira não, porque eu penso assim, assim e assim; e eu acho que elas querem que eu pense diferente e isso é um mal pra mim!' (MARIA LUIZA, 2016). 
A religião católica pregada no colégio não cumpriu seu papel, no caso de Maria Luiza. Isso porque, apesar do exercício disciplinador com a utilização de instrumentos simples, como a vigilância hierárquica e a sanção normalizadora (FOUCAULT, 1998), o intuito de adestramento não foi alcançado. Maria Luiza não internalizou o modelo mariano de educação e questionou com seu pai a educação feminina recebida, recordando os momentos de punição sofridos na escola. As atribuições de condutas aos pecados eram os modos como os colégios e as famílias podiam manter os padrões rígidos sociais, preservando sempre os valores que formavam as elites da sociedade brasileira durante $o$ século XX; no entanto, o senhor Antonino Fontenele, seu pai, cedeu aos argumentos de Maria Luiza e a transferiu de escola.

Como era de costume, nas cidades interioranas, quando os filhos das famílias mais abastadas alcançavam o último nível de educação formal disponível na região, eram encaminhados para as capitais, a fim de prosseguirem nos estudos. Dessa forma, Maria Luiza mudou-se, mais precocemente do que o planejado pela família, para a casada irmã mais velha, já casada, em Fortaleza, onde estudou no Colégio Nossa Senhora de Lourdes, cursando o final do primário e os quatro anos do ginasial. Essa instituição era considerada de referência para a educação feminina no Ceará, conforme sublinha Girão:

[...] Colégio nossa Senhora de Lourdes (externato e internato), fundado e dirigido pela intelectual Ana Bilhar e destinado ao sexo feminino. Iniciado em 1889, na Serra de Guaramiranga, transferiu-se em 1896 para Fortaleza. Professorado escolhido e escolhido currículo. A sua orientação pedagógica ajustava-se ao que de melhor havia naquela época. Sabia dar o máximo de brilho e distinção social e artística às suas festas e solenidades (GIRÃO 1962, p. 288).

Esse colégio, como se constatou, oferecia regime de internato e externato, Maria Luiza permaneceu interna durante seis anos. O objetivo dessa instituição era preparar seus alunos para a inserção gradual na sociedade urbana, que seguia padrões burgueses de comportamento (FREITAS; BICCAS, 2009), tais como: ser boa dona de casa, saber cozinhar, costurar, ser recatada, discreta, obediente, temente a Deus etc. A formação de Maria Luiza no internato do Colégio Nossa Senhora de Lourdes contribuiu para que ela substituísse a mentalidade rural ao incorporar normas de conduta da sociedade emergente, uma vez que a instituição ajudou na elaboração de vínculos com as alunas, em detrimento dos laços familiares que até então eram mais fortes. Nesse momento de mudança de colégio e de cidade, Maria Luiza substituiu a vivência da família e do sítio pela noção de cidade.

Para esse novo contexto, a instituição propagou além da formação para o matrimônio, o ensino de boas maneiras e de urbanidade, para que as moças percebessem que, além do espaço doméstico, havia o espaço social com suas características próprias a serem compreendidas e respeitadas. À mulher cabia a fineza dos modos, as habilidades artísticas, o refino musical e literário a serem exibidos em saraus, festas e/ou reuniões familiares (AZZI, 2008). Na visão de Maria Luiza, porém, o mundo podia ser outro: 


\begin{abstract}
Bom, aí tudo que você puder imaginar que uma pessoa pudesse fazer, sendo interna, eu fiz.Aliás, não fiz porque eu não peguei a área do esporte, eu peguei a área da Arte e a área da visitação, por que eu queria sair do colégio, num dava para ficar todo o tempo ali, né?! Então, dia de domingo tinha uma missa cinco horas da manhã, e eu preferia acordar de madrugada e ir pra missa às 5 h da manhã para ver o povo na outra igreja e andar na rua, do que assistir a missa que tinha no colégio. Eles diziam: 'Quem quer assistir a missa de 5h?!'Eu era uma das primeiras, e participava de tudo quanto era dramatização, participava de todo tipo de dança! Era balé, era num sei mais o quê, participava de tudo! E estudava música, no piano, mas quando a freira dava as costas eu ia para música da amplificadora, eu tocava música, então, eu tenho registrado na minha memória acho que quase todas as músicas daquela época (MARIA LUIZA, 2016).
\end{abstract}

Maria Luiza continuou problematizando os ideais da religião católica, o que a levou a buscar mecanismos de fuga do regime interno nessa Instituição também. A diferença consistia no fato de que, no Colégio Nossa Senhora de Lourdes, era muito comum a realização de eventos que integravam a comunidade e havia menor isolamento social das internas. As festas escolares eram periódicas e realizadas com muita solenidade, nas quais as famílias e as autoridades locais se faziam presentes para apreciarem os resultados obtidos através da ação educativa das irmãs. Tornou-se possível identificar que a educação ministrada pelas religiosas objetivava a manutenção dos valores tradicionais, porém com características para a formação de um público letrado e urbano.

Além da instrução religiosa e da formação moral, as prendas domésticas, a pintura e os bordados ajudavam a compor o currículo escolar e dar prestígio à figura da mulher, a quem, além da beleza, deveriam ser atribuídos dotes do espírito e da cultura letrada. No que se refere à organização do ensino, durante todo o século XIX, e em boa parte do século XX, torna-se clara uma disputa entre os estudos científicos e os literários (isso também em outros países ocidentais) em todo o território brasileiro, para o ideal de formação da juventude. Os estudos literários valorizavam a retórica, a linguística, a expressão dos sentimentos, a natureza humana e o autoconhecimento; enquanto os estudos científicos (Ciências) valorizavam a racionalidade, a observação empírica, o conhecimento da natureza e o conhecimento útil (SOUZA, 2008).

Percebe-se essa organização dicotômica no Colégio Nossa Senhora de Lourdes onde, de um lado, havia a defesa pela formação da cultura humanística (cultura literária); de outro lado, a defesa do conhecimento científico, que priorizava elementos úteis para ocupações no mundo do trabalho (cultura científica). Contudo, para as mulheres, além do ensino científico estar associado às prendas do lar, não se estimulava o prosseguimento aos estudos em nível superior, pois a aquisição de um bom casamento era o destino reservado às mulheres de boa família.

Após a conclusão do ensino primário nas instituições católicas supracitadas, Maria Luiza decide fazer o exame de admissão para ingressar no Curso de Ensino Secundário do Liceu do Ceará. Essa instituição, destinada à formação das elites, tinha um ensino pautado na cultura literária e humanística, enquanto os conteúdos científicos não tinham tanta relevância, 
fato que gerou muitos debates e discussões, pois os educadores afirmavam que, para o Brasil alcançar a modernização que desejava, a elite que estava sendo formada deveria receber o conhecimento científico (SOUZA, 2008). Os conteúdos deste nível de ensino estavam presentes no Brasil desde o Período Colonial, através da ação da Igreja Católica.

O Liceu do Ceará, inspirado no Colégio Pedro II, do Rio de Janeiro - que foi um estabelecimento de referência para as demais instituições de ensino secundário do país -, foi criado em 15 de julho de 1844, e instalado apenas em 10 de outubro de 1845, pelo presidente de província, José Maria da Silva Bittencourt. Essa Instituição representa um marco para a historiografia da educação no Ceará, pois, a partir da sua criação, a instrução pública nesse território passa para uma nova fase, já que o currículo do Liceu estava pautado na formação humanística e clássica, em que, de acordo com o art. 1 da Lei de n. 304, seriam reunidas as cadeiras de "[...] philosoohia racional e moral; rhetorica e poética; arithmetica; geometria; trigonometria; geographia; historia; latim; francez e inglez".

Além de Tomás Pompeu de Sousa Brasil, que assumia a função de diretor e de lente catedrático de Geografia e História, contava-se com vários outros catedráticos:

O ilustre Padre Severino Duarte veio reger a cadeira de Latim; o médico José Lourenço de Castro e Silva, já muito reputado, a de Francês; Gonçalo de Almeida Souto, posteriormente graduado em Direito, a de Inglês; o Dr. Joaquim Saldanha Marinho, a das matemáticas; o bacharel Manuel Teófilo Gaspar de Oliveira, a de Retórica; Manuel José de Albuquerque, jornalista e professor, a de Filosofia. A de Geografia e História coube ao próprio diretor que, achando falho o travejamento técnico do educandário nos moldes da legislação que o criou, eruditamente traçou a respectiva reforma adaptando-o a modelo adequado (GIRÃO, 1962, p. 285).

Como é possível constatar, os professores do Liceu eram bacharéis em Direito, médicos, padres, jornalistas e/ou pessoas de destaque na política. O modelo de formação dessa instituição destinava-se a uma parcela privilegiada da sociedade: os futuros "dirigentes da sociedade". Sobre o ensino do Liceu, a biografada acrescenta:

O Liceu era considerado, à época, o melhor colégio de Fortaleza; e todos os professores eram muito exigentes. Além do mais, você tinha disciplina de Química, Física, que são extremamente difíceis. Nós sofremos muito para ter um bom desempenho nisso aí. E à época o professor de História era simplesmente divino, você tinha a sensação de que tava viajando com ele pela Europa e por todo canto; tão especial era a aula que ele ministrava. Mas tinha dois professores que eu tinha, digamos, uma relação melhor (MARIA LUIZA, 2016).

Suas experiências de formação secundária no Liceu do Ceará estiveram estritamente relacionadas aos movimentos estudantis. Ela participou das eleições de chapa para o Centro Liceal de Educação e Cultura (CLEC), que, na época, organizava um movimento de reivindicações sociais e possuía caráter filosófico, tendo em vista que possibilitava aos estudantes debates sobre questões sociopolíticas e artísticas, inclusive com produções em 
jornais locais. A experiência na gestão CLEC foi fundamental para a iniciação política de Maria Luiza, que começou a compreender processos de organização em chapa, votação, atribuições de líderes, participação, maneiras de reivindicação de causas coletivas, autonomia e tomada de decisões.

A partir da identificação e do envolvimento com o CLEC, Maria Luiza inicia um caminho de atividades sociais e políticas: primeiramente, buscava melhorias para os estudantes secundaristas; em seguida, na JEC (Juventude Estudantil Católica), elegeu como proposta formar para a competência, para a ação e para a perfeição, através de uma concepção diferenciada de perceber o homem como um ser social e atuante, e a religião, como mecanismo propulsor desse protagonismo. No ensino superior, sua participação na JUC (Juventude Universitária Católica) dá continuidade ao engajamento com os movimentos estudantis; desta vez, com maior amplitude de escopo, vislumbrando garantia de direitos para a sociedade menos favorecida economicamente.

Tais ideais parecem ter sido incorporados por Maria Luiza; e o seu envolvimento como CLEC, e, principalmente, com a JEC e a JUC - que possuíam embasamento teórico marxista (DUARTE, 2010) - acabou por resultar na aproximação de Maria Luiza com os partidos de esquerda, fato que a afastou (juntamente com outros jovens de seu tempo) da igreja católica, já que esta recebia maior influência da força conservadora. A partir desse rompimento, a JUC passa a ser alvo da repressão política e policial, caracterizando um cenário político de embates, no Ceará e no Brasil, no período pós-1964. Outra consequência do rompimento da JUC com a Igreja foi o abandono do discurso desenvolvimentista, tão disseminado nessa organização, em troca da emergência de um posicionamento revolucionário, de caráter nacional e anti-imperialista.

A formação recebida por Maria Luiza Fontenele no ensino secundário, especialmente inspirada em uma professora singular, preparou-a para a liderança e a inserção política. Nesse período, ela já protagonizava movimentos no contexto de atuação na sociedade, de forma sistemática. Como líder de turma, ela explica como funcionava a escola de líderes do Liceu:

[...] com reuniões preparatórias que a gente adquiria responsabilidade de levar ao colegiado o interesse da turma e as preocupações que a gente tinha com o colégio; e então era uma coisa extraordinária, bem como um acompanhamento muito grande dela, da professora Irene. E eu comecei a achar que ela tinha aquela postura porque ela era assistente social, ou seja, o interesse pelos alunos, o interesse pelas lideranças para que a gente pudesse tornar o colégio cada vez melhor, então eu, por intermédio dela, eu comecei a me interessar pelo Pirambu (MARIA LUIZA, 2016).

O Pirambu foi um bairro de Fortaleza-CE esquecido pelos governantes locais durante muitos anos por representar um local marginalizado, onde se encontravam perigosos, prostitutas e doentes (OLIVEIRA, 2014). Nesse espaço, Maria Luiza iniciou o desenvolvimento de vários projetos sociais, a partir de estágios do Liceu do Ceará. Desde a influência de Irene e o envolvimento com a militância popular do Pirambu, Maria Luiza motivou-se a cursar Serviço Social, no nível superior de ensino. A relação com o Pirambu estendeu-se por muitos anos, sendo o bairro com maior índice de votos à Maria Luiza, durante as eleições para a prefeitura de Fortaleza, em 1985. 


\section{A graduação em Serviço Social no contexto da Ditadura civil-militar}

Maria Luiza ingressa na Escola de Serviço Social - anexa à Universidade Federal do Ceará, que, após dezoito anos foi incorporada à Universidade Estadual do Ceará - no ano de 1962, período em que esse curso de graduação ainda se estava estruturando no Brasil. Dois anos após a entrada no ensino superior, Maria Luiza, que já havia adquirido representatividade ao fazer parte do Centro Acadêmico do Curso de Serviço Social, participa de um movimento de resistência contra o golpe militar estabelecido em 1964.

O contexto político de 1964 significou a queda do processo de democratização no Brasil. O País já havia apresentado notável crescimento de organização e de participação política dos trabalhadores, tanto os da cidade quanto os do campo, nas decisões políticas e econômicas e a tentativa de realização de uma Reforma de Base. Os anos seguintes ao golpe, que retirou João Goulart da presidência da República, significaram um regime militar que se utilizava das forças das armas, da violência e da repressão para silenciar os opositores aos ideais do novo governo.

Os militares tomaram o poder e criminalizaram pessoas, atividades e movimentos oposicionistas, além de retirarem os direitos humanos fundamentais da sociedade; "a tutela militar acompanhou a ditadura do berço à cova: foram os altos mandatos militares que estiveram à frente do regime e que o sustentaram, mediante a coerção, por vinte anos". Essa tutela militar priorizou direitos das classes mais favorecidas economicamente e dos grandes latifundiários, secundarizando o investimento nos diversos problemas sociais e econômicos enfrentados pela população mais pobre (PAULO NETTO, 2014, p. 83).

O governo estadual do Ceará, na figura de Virgílio Távora, demonstrou-se favorável ao golpe militar e declarou posição de defesa pela ordem e pela segurança pública do Estado, contra a "onda vermelha" e ao comunismo local. Virgílio consolidaria o governo militar no Estado, tomando medidas em consonância com o golpe civil-militar e legitimando o movimento militar, prestando um "bem à pátria" (COSTA, 2015).

A Educação sofreu fortes transformações após o golpe militar de 1964, já que era necessário adequar o ensino aos interesses e às necessidades do mercado, que se ampliava, cada vez mais, às empresas estrangeiras. As modificações foram iniciadas pelo ensino superior, com o favorecimento à privatização do ensino (SAVIANI, 2008). Maria Luiza assevera tal postulado ao narrarque esse cenário político interferiu em sua formação superior, pois ainda que o Curso de Serviço Social tenha resistido à perseguição militar e ao autoritarismo, as mudanças nas práticas pedagógicas foram implantadas por medo da perseguição:

Houve um período assim um pouco de retrocesso, porque como eles estavam prendendo muita gente e muita gente caindo na clandestinidade, então a gente tinha certo receio e tínhamos uma questão muito grave, que era a questão da igreja, a igreja recuou bastante [...] (MARIA LUIZA, 2016) 
Sem a proteção da igreja e com a perseguição militar aos professores universitários, especialmente dos cursos mais resistentes ao regime, com inserção social e protagonismo nos movimentos sociais, como era o caso do Serviço Social, muitos professores alteraram sua práxis pedagógica temendo a repressão assistida pelas prisões de colegas de profissão.

O setor de direita da Igreja Católica manteve-se firme ao apoiar o governo militar, até o momento em que padres, movimentos e pastorais iniciaram um processo de repúdio às medidas adotadas durante o regime militar nos diversos setores da sociedade, porém essa "tomada de consciência" foi tardia, segundo Maria Luiza. O fato de manter boas relações com padres e leigos envolvidos em movimentos considerados de resistência na Igreja Católica, como a JEC e a JUC, contribuiu para que ela ganhasse apoio do setor popular dessa instituição recebendo proteção da Igreja Católica, que a livrou de muitas perseguições, diferente de outras mulheres e militantes, no mesmo período, que não tiveram apoio de nenhum órgão ou instituição e foram fortemente perseguidas, torturadas e violentadas. Importa destacar que nem sempre a solidariedade dos "revolucionários católicos" pôde defendê-la e livrá-la de responder a processos judiciais; no entanto, estes não resultaram em perseguição, tortura ou prisão, mas representaram um sofrimento psicológico, devido aos incansáveis interrogatórios de que foi obrigada a participar por seu movimento estudantil ser alvo policial.

Estudantes e leigos se organizaram em conselhos, movimentos, alianças e demais associações para atuarem de forma expressiva na transformação da realidade social, levantando a importância da militância de esquerda. Os documentos elaborados pela Ação Popular Católica (AP) possuíam conteúdo teórico e ideológico na defesa do socialismo, no qual o ideário não apenas criticava o capitalismo vigente no Brasil mas também defendia uma revolução brasileira a fim de se alcançar uma transformação radical na sociedade tornando-a mais igualitária.

Aos poucos, esse movimento da AP recebia também militantes que não se designavam cristãos, principalmente no meio estudantil, o que estreitava a relação com a União Nacional dos Estudantes (UNE) e, posteriormente, com o Partido Comunista Brasileiro (PCB). A teoria marxista, como fonte, contribuiu para a formação da consciência dos integrantes da AP que visavam disseminar seus ideais para a classe trabalhadora. Vale lembrar que,

[...] para a AP, a noção de consciência política pressupõe o engajamento político dos homens em busca da superação das chamadas 'relações de dominação' estabelecidas pelo sistema capitalista, promovendo, assim, a humanização do mundo através da realização do homem (DUARTE, 2010, p.36).

Foi essa fundamentação teórica que Maria Luiza tomou para si durante seu engajamento nos grupos da AP católica. O reconhecimento das relações de poder e a internalização de pressupostos cristãos, contribuíram para a sua formação como mulher e para sua atuação profissional/militante, sempre em busca da superação de problemas sociais, com a finalidade de alcançar a formação de uma consciência emancipatória. 
O Movimento Estudantil pelo qual Maria Luiza militou quando estava na universidade representou uma organização de forte resistência contra o militarismo implantado. Mas esse agrupamento só apresentou maior fortalecimento e organização quando passou a ser liderado pela UNE, em 1970 (POERNER, 1979).

O Movimento Estudantil foi um espaço de formação, ainda que não formal, pois além de contribuir com a aprendizagem e desenvolver a construção da cidadania de seus participantes, fortaleceu a conscientização política dos estudantes na universidade (POERNER, 1979). Ao conceder autonomia ao estudante nos espaços deliberativos, o Movimento Estudantil constituiu-se como fundamental para a inserção política de Maria Luiza, configurando-se o primeiro espaço de atuação política de muitos estudantes. Consideramos que ela passou por processos efetivos de formação, conscientização de democracia e construção da coletividade durante sua atuação nos movimentos estudantis, principalmente pela efervescência política do período da ditadura militar no Brasil.

A formação em Serviço Social durante o contexto da ditadura militar aflorou ideais pelos quais continuaria lutando no decorrer da sua vida. A passagem pelos movimentos estudantis e católicos constitui fases de sua identidade como professora - quando foi convidada para integrar o corpo docente do Curso de Ciências Sociais da Universidade Federal do Ceará, em 1967 - e como militante política - através da atuação sindical na Associação dos docentes das Universidades Federais do Ceará (ADUFC), na União das Mulheres Cearenses (UMC) e através dos mandatos políticos, como Deputada Estadual (1979), como Prefeita (1985) e como Deputada Federal (1990).

\section{Considerações Finais}

A pesquisa questionou como se deu a educação oferecida à Maria Luiza Fontenele familiar, primária, secundária e universitária - para que ela pudesse se tornar uma líder política que galgou prestígio e visibilidade social em tempos em que apenas homens ocupavam os espaços decisórios na política brasileira. Para responder a esta inquietação, desenvolveu-se uma pesquisa que objetivou compreender o curso formativo na educação familiar, primária, secundária e universitária, bem como a inserção política (1950-1965) de Maria Luiza. Mediante o procedimento metodológico da História Oral no gênero biográfico, obtivemos acesso às suas narrativas, o que se deu por meio de entrevistas livres que formaram a principal fonte para a compreensão de sua trajetória de educação e de sua inserção política na relação com o contexto social e histórico do início da segunda metade do século XX no Ceará-Brasil.

A formação recebida por Maria Luiza Fontenele em casa consistiu na instrução elementar ministrada por professora leiga, no ensino denominado de "Primeiras Letras", que lhe permitiu ler, escrever, contar de acordo com as quatro operações básicas e vivenciar a Doutrina católica apostólica romana e seus princípios morais, bem como as regras de civilidade. O ensino primário, nos colégios de freiras, possuía foco na cultura científica e literária. Por serem instituições de referência para as "moças" de prestígio no contexto da educação cearense do século XX (GIRÃO, 1962), eram consideradas de qualidade. Mas a formação escolar, com princípios cristãos, foi questionada desde muito cedo por Maria Luiza, que problematizou a educação feminina voltada para a servidão, a obediência e a submissão à 
autoridade masculina. Com essa visão de mundo, mostrou-se sempre disposta a romper com os paradigmas impostos, mesmo sendo constantemente punida por seus comportamentos considerados indevidos.

O ensino secundário no Liceu do Ceará, instituição de referência para a formação da elite cearense (pautado na formação humanística e de acordo com o modelo do Colégio Pedro II), no Rio de Janeiro, além de um currículo complexo, permitiu à Maria Luiza a participação no grêmio, na edição do jornal e nas atividades culturais do colégio. Essas experiências contribuíram, tanto para a elaboração de conhecimento quanto para a intensificação de sua postura autônoma, com desenvoltura para defender suas convicções e desenvolver aptidão para o ensino.

O seu engajamento e sua militância nos grupos católicos (JEC e JUC), nos movimentos estudantis (CLEC e Centro Acadêmico) e sociais (Bairro Pirambu) contribuíram para a sua formação docente e para sua atuação militante, sempre em busca da superação de problemas sociais, com a finalidade de alcançar a formação de uma consciência emancipatória. Os movimentos estudantis, em que militou, antes e durante a ditadura civilmilitar, podem ser considerados como o espaço de formação inicial para a inserção política de Maria Luiza, vez que lhe favoreceram o desenvolvimento da politização e da conscientização, aspectos que futuramente estariam no cerne de sua atuação como política, e no sindicato dos professores, amadurecendo ainda mais a reflexão sobre as condições sociais do homem no trabalho, na sociedade, na universidade.

Considera-se que este estudo fomenta possibilidades de ampliação dos conhecimentos sobre as relações entre História da Educação e memória, bem como dos imaginários e mentalidades individual e coletiva, já que ambas se imbricam. Salienta-se, contudo, que um estudo micro-histórico no campo da história cultural não permite generalizações, mas possibilita desvelar nuances subjetividades e individualidades, invisíveis pela macro-história, que são pertinentes para uma melhor compreensão historiográfica. Portanto, a força educativa de um relato biográfico não pode ser desvalorizada.

\section{Referências}

ALBERTI, Verena. Histórias dentro da história. In: PINSKY, Carla (Org.) Fontes históricas. São Paulo, Contexto, 2005.

AZZI, Riolando. A Igreja Católica na formação da sociedade brasileira. Aparecida: Editora Santuário, 2008.

BRAGA NETO, Aristides. O Diário do Nordeste sobre a administração popular de Fortaleza: palavras de oposição. 2011. 242f. Dissertação (Mestrado em História) - Programa de Pós-Graduação em História, Universidade Estadual do Ceará, Fortaleza, 2011.

BRASIL. Lei de 15 de outubro de 1827. Manda crear escolas de primeiras letras em todas as cidades, villas e logares mais populosos do Imperio. Coleção de Leis do Império do Brasil. Rio de Janeiro: Typographia Nacional, 1827. (v. 1, pt. I). Disponível em: http://www2.camara.leg.br/legin/fed/lei_sn/1824-1899/lei-38398-15-outubro-1827-566692publicacaooriginal-90222-pl.html. Acesso em: 25 out 2017. 
BRILHANTE, Matilde de Lima. Um passado em traços: charge e a produção de sentidos sobre a "administração popular" de Fortaleza (1985-1988). 2011. 174 f. Dissertação (Mestrado em História) - Programa de Pós-Graduação em História, Universidade Estadual do Ceará, Fortaleza, 2011.

BURKE, Peter. A escrita da História: novas perspectivas. Tradução de Magda Lopes. São Paulo: Editora da Universidade Estadual Paulista, 1992.

O que é história cultural? Tradução Sergio Goes de Paula. 2. ed. Rio de Janeiro: Jorge Zahar Editora. 2008.

CALIXTO, Francisco José Silva. Memória e narrativa: a história da educação da Administração Popular de Fortaleza (1986-1988). 2002. 116f. Dissertação (Mestrado em Educação) - Programa de Pós-Graduação em Educação, Universidade Federal do Ceará, Fortaleza, 2002.

CASTELO, Plácido Aderaldo. História do ensino no Ceará. Fortaleza: Departamento de Imprensa Oficial, 1970.

COELHO, Rebeca do Nascimento. Contextos de participação política de mulheres: as candidaturas das prefeitas Maria Luiza Fontenele (1985) e Luizianne Lins (2004). 2014. 128 f. Dissertação (Mestrado em Sociologia) - Programa de Pós-Graduação em Sociologia, Universidade Federal de Pernambuco, Recife, 2014.

COSTA, Jucelio Regis da. Os jornais em marcha e as marchas da vitória nos jornais: A imprensa e o Golpe Civil Militar no Ceará(1961-1964). Dissertação (Mestrado em História Social) - Programa de Pós-Graduação em História Social, Universidade Federal do Ceará, Fortaleza, 2015.

DUARTE, Hugo Villaça. A Ação Popular e a questão humanista: das origens cristãs ao marxismo (1963-1973). 2010. 133f. Dissertação (Mestrado em História) - Programa de PósGraduação em História, Universidade Federal Fluminense, Rio de Janeiro, 2010.

FERREIRA, Marieta de Morais. História oral: um inventário das diferenças. In: FERREIRA, Marieta de Morais (Org.). Entre-vistas: abordagens e usos da história oral. Rio de Janeiro: Editora da Fundação Getúlio Vargas, 1998.

FIALHO, Lia Machado Fiuza; CARVALHO, Scarlett O’hara Costa. História e memória do percurso educativo de Célia Goiana. Série-Estudos, Campo Grande, v. 22, n. 45, p. 137-157, maio/ago. 2017.

FOUCAULT, Michel. Vigiar e punir: nascimento da prisão. Petrópolis: Vozes, 1998.

FREITAS, Marcos Cezar de; BICCAS, Maurilane de Souza. História social da educação no Brasil (1926-1996). São Paulo: Cortez, 2009.

GIRÃO, Raimundo. Pequena história do Ceará. 2. ed. Fortaleza: Editora Instituto do Ceará, 1962. 
LE GOFF, Jacques. História e memória. Campinas: Editora da Unicamp, 1990.

LORIGA, Sabina. O pequeno X: da biografia à história. Tradução Fernando Scheibe. Belo Horizonte: Autêntica Editora, 2011.

MACHADO, Charliton José dos Santos. Mulher e educação: histórias, práticas e representações. João Pessoa: Editora Universitária - UFPB, 2006.

MAIA, S. S.; BRAGA, V. R. S.; FIALHO, L. M. F. Biografia de idosos: uma fonte para pesquisas. In: FIALHO, L. M. F.; SANTANA, J. R.; VASCONCELOS, J. G. (Org.). Fontes orais em pesquisas educacionais. Fortaleza: Edições UFC, 2015.

MEIHY, José Carlos Sebe Bom; HOLANDA, Fabíola. História oral: como fazer, como pensar. São Paulo: Contexto, 2007.

MARIA LUIZA. Entrevista. Fortaleza (Ceará), 12 set. 2016.

MEDEIROS FILHO, João; SOUZA, Itamar de. Os degredados filhos da seca: uma análise sócio-política das secas no Nordeste. 2. ed. Petrópolis: Vozes, 1983.

MENEZES, Djacir. A educação no Ceará. Repasse histórico-social (das origens a 1930). In: MARTINS FILHO, Antonio; GIRAO, Raimundo. O Ceará. 3. ed. Fortaleza: Instituto do Ceará, 1966.

OLIVEIRA, Raimundo Nonato Nogueira de. A Igreja Católica no Pirambu: As relações de poder presentes no discurso da Teologia da Libertação e da Renovação Carismática Católica (1968-1986). Dissertação de Mestrado. Fortaleza: Universidade Federal do Ceará, 2014.

PAUlO NETTO, José. Pequena história da ditadura brasileira (1964-1985). São Paulo: Cortez, 2014.

POERNER, Artur José. O poder jovem: história da participação política dos estudantes brasileiros. 2. ed. Rio de Janeiro: Editora Civilização Brasileira, 1979.

POLLAK, Michael. Memória e identidade social. Estudos Históricos, Rio de Janeiro, v. 5, n. 10, p. 200-212, jul./dez. 1992.

SAVIANI, Dermeval. O legado educacional do regime militar. Cadernos Cedes, Campinas, v. 28, n. 76, p. 291-312, set./dez. 2008. Disponível em: http://www.scielo.br/pdf/ccedes/v28n76/a02v2876.pdf. Acesso em: 27 mar. 2017.

SOUZA, Rosa Fátima de. História da organização do trabalho escolar e do currículo no século XX (ensino primário e secundário no Brasil). São Paulo: Cortez, 2008.

SILVA, Kalina Vanderlei. Dicionário de conceitos históricos. 2. ed. São Paulo: Contexto, 2009.

THERRIEN, Jacques. A professora leiga e o saber social. In: GARCIA, Walter (Org.). Professor leigo: institucionalizar ou erradicar. São Paulo: Cortez, 1991. 
VASCONCELOS, Larissa Meira de; FIALHO, Lia Machado Fiuza; MACHADO, Charliton José dos Santos. Educação, gênero e higienismo nos anúncios publicitários da Paraíba durante a Primeira República. Cadernos de História da Educação, Uberlândia, v. 16, n. 2, p. 451-473, maio/ago. 2017. Disponível em: http://dx.doi.org/10.14393/che-v. Acesso em: 15 out. 2017.

VIDAL, Diana Gonçalves; FARIA FILHO, Luciano Mendes de. As lentes da história: estudos de história e historiografia da educação no Brasil. Campinas: Autores Associados, 2005.

VIEIRA BRUNO, Artur José; FARIAS, José Airton de; ANDRADE, Demétrio. Os pecados capitais do Cameba. Fortaleza: Editora Expressão Gráfica, 2002. 